Dr. Ayman Ibrahim Elhalafawy

\title{
Stereotyping Chicanos in Ethnic Theatre: A Study of Luis
} Valdez's Zoot Suit

by

\author{
Dr. Ayman Ibrahim Elhalafawy \\ An Associate Professor of English Literature \\ Faculty of Arts \\ Kafrelsheikh University
}

\begin{abstract}
This paper investigates ethnic theatre in general, and Chicano theatre in particular, with a particular reference to Luis Valdez's famous play Zoot Suit. This paper is divided into two main parts. The first part tends to be an introductory theoretical one. It begins by surveying the history and development of the ethnic and Chicano theatres in the United States examining their impact on society. This part, also, highlights the remarkable role of Luis Valdez as the father of the Chicano theatre. The second part of the paper provides a comprehensive analysis of Valdez's Zoot Suit in order to find out how Chicanos are stereotyped in the play.
\end{abstract}

\section{Keywords:}

Ethnic theatre, Chicanos, Luis Valdez, the United States, stereotype, Zoot Suit.

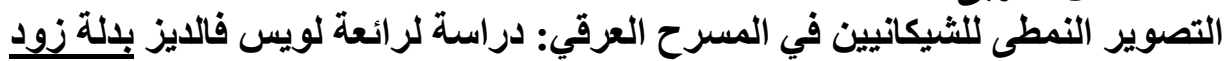

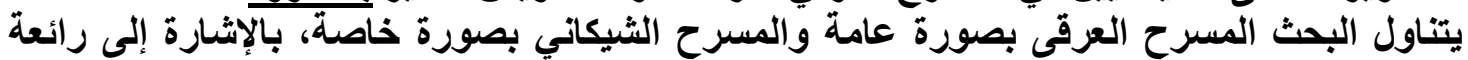

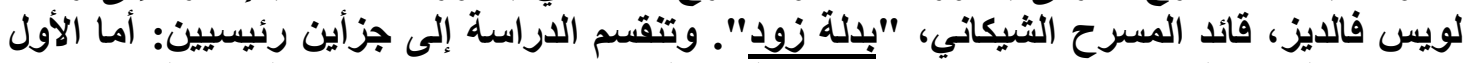

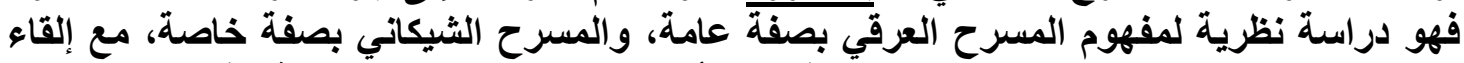

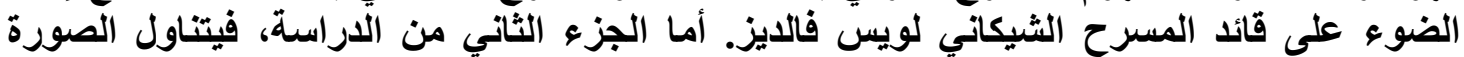

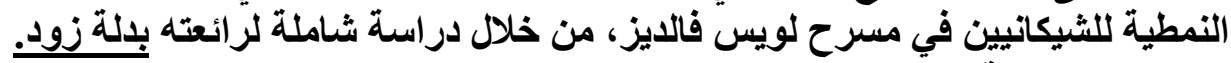

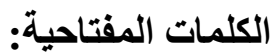
المسرح العرقي - الثيكاتيون- لويس فالديزة - الولايات المتحدة ـ الصورة النمطية_بدلة زود. In the late eighteen and early nineteenth centuries, millions of immigrants left their original homes and migrated to the United States. These immigrants formed new communities in the American society. Such immigrant communities had different historical, religious, cultural and artistic traditions. Coming to the United States, immigrants had to develop new intellectual and social institutions that represented them in the new world to which they migrated. One of the most interesting and significant institutions that reflect the nature of life of these communities was their theatre. Springing from diverse racial and cultural origins, theatre varied in style and content from one immigrant community to another.

The main objective of this paper is to examine ethnic theatre generally, and Chicano theatre particularly, illustrating the roles they have played in the lives of immigrant communities within the American society. Equally important, the present study aims to shed the light on the 
famous American dramatist Luis Miguel Valdez (1940- ) and his remarkable Chicano play Zoot Suit (1979).

The origin of ethnic theatre is, in fact, connected with the immigrant generations to the United States. Thus, ethnic theatre arises from a remarkable mix of different cultural backgrounds and traditions. For example, African American theatre emerged from black slaves who were brought to the United States from the eighteenth century onwards. Those slaves brought their language and cultural traditions to the American society in which they formed a new theatre tradition based on their cultural heritage. Afterwards, the number of European and Asian immigrants to America became notable in the nineteenth century.

Ethnic theatre remarkably flourished in the early twentieth century due to a huge wave of immigration during this century. Ethnic theatre was the only theatre that provided inexpensive entertainment in the immigrants' native languages. These theatres were sponsored by different local institutions such as churches, youth groups, athletic clubs, and universities. Many immigrants tried to act in theatres themselves or to become writers and directors.

Ethnic theatres depended on professional actors and directors who were previously trained in their native countries. However, ethnic theatre faced different kinds of conflicts due to the immigrant communities themselves. These members had different views on what lifestyle and religious traditions should be in the new country. Accordingly, immigrants had to choose whether to adhere to the traditions of their backgrounds or to deal with new opposing ones.

Most noticeably, ethnic theatre became a necessary institution that achieved social, cultural, and educational importance for ethnic groups. For most immigrants, theatre became a necessity for their entertainment. The life of these immigrants was, painfully, full of poverty and suffering. As a result, they were looking first for entertainment. Thus, they spent their few hours of entertainment in ethnic theatres in order to forget the hardships of their daily life:

I do not go to the theatre to think but t o forget, "wrote a Jewish immigrant who called himself ' the average theatre goer.' I seek there to forget my wife, the children, the crowded tenement. the littered wash... 1 want to see men dressed in armor or in the costumes of wealthy shepherds who wear silk chemises... when I am in... theatre ... I see on the stage a beautiful room with expensive furniture and chandeliers... I am just a poor fellow ... and all this costs me but half a dollar. Isn't it worth it? (Nadir 9) 


\section{Dr. Ayman Ibrahim Elhalafawy}

Moreover, ethnic theatre represented a social centre .This social world of the theatre was important for immigrants who wanted to improve English. Thus, ethnic theatre became an effective institution in bringing together people from different ideological and cultural backgrounds.

Ethnic theatre, in addition, supported women on a different level. On ethnic stages, women were finally able to find a way to use their talents and fulfill their dreams by escaping their traditional domestic roles. They became independent from men by earning their own money. Working for bigger theatres, women were able to travel to other countries getting acquainted with new lifestyles. They were able to become successful as actresses, directors, producers, and owners of theatres.

Many researchers, such as Galda and Cullinan in their book Literature and the Child and Jenkins and Austin in their book Literature for Children about Asians and Asian Americans, have classified certain criteria that should be traced for any literary work to be described as ethnic. These points will be summarized as follows: the work must (1) contain language that provides insight into the culture of the group (2) avoid racial and cultural negative stereotypes, (3) present cultural details accurately such as food, dialects, customs and clothing, (4) expose cultural authenticity and the experiences honestly (Galda and Cullinan 285), (5) attempt to amend historical errors or omissions, (6) contain illustrations that are true reflection of the way of life and (7) depict women in transition from traditional to contemporary( Jenkins and Austin 20).

Chicano literature, or Mexican-American literature, refers to literature written by Chicanos in the United States. Historically, although its origins can be traced back to the sixteenth century, Chicano literature dated to same time after the Mexican-American war of 1848. It is chiefly associated with the social and cultural claims of the Chicano movement shaped by a number of intellectuals and activists to create a strong sense of self- identity advocating Chicano civil rights. Chicano literature, mainly, focuses on themes of identity, discrimination and ethnicity focusing on the Mexican-American experiences or Chicanos' culture in the United States. In addition, the most important themes of Chicano literature include the experience of migration and the relation between two languages. It is generally written in either English or Spanish or mixture of the two: Spanglish.

The definition of Chicano or Mexican-American includes both Mexicans who have moved to the United States and the American born people of Mexican ancestry including those who have lived in Texas, New Mexico, Arizona, and parts of California. Chicanos have been 
considered as a linguistic and cultural minority as they were composed mostly of Spanish-speaking Catholics living in an English-speaking Protestant country. Chicano literature also has a specific racial nature. William Estrada (2016) reveals that some Mexican-Americans define themselves as mestizo, people with a mixture of primarily indigenous and European heritage, while others fit within the Hispano demographics of people with primarily Spanish heritage. African-descended Mexicans also contribute to this field, with the last governor of Alta California, Pío Pico, having African heritage (10).

For Chicanos, cultural roots are important. In fact, Chicanos were often forced to adopt a dual culture and a hybrid identity in America. In the 20th century, they learned to speak English and adapt to the American culture. However, they were still heavily influenced by their original Mexican culture. They have been targeted racially since 1848 and often responded by rejecting the label "brown" throughout history when being "white" was dominant (Irene Blea, 1997).

As a result, the term "'Chicano" was born as a term of ethnic identification. It has been applied by "Mexican Americans in a derogatory sense to refer to another Mexican American of a lower class" (Steinbeck et al., xii). Nowadays, however, it is being used to identify the Mexican American as he is giving him a due self estimation; that is "a product of a Spanish-Mexican-Indian heritage and an Anglo-Saxon (American, or, as they say, in Mexico, Estado Unidense) influence" (Aguirre et al. 2). Therefore, Chicanos are bilingual and hybrid.

Mostly significant, Chicanos have not been truly represented in American literature. Their racial and cultural features have been ignorantly exaggerated and negatively stereotyped. Because of the biased portrayal of Mexican Americans as uncivilized minority in the United States, Chicano stereotypes have reflected the writers' ignorance of the culture of this minority. It has contributed to maintaining Mexican Americans repressed by influencing social attitudes. It has also generated feelings of racial superiority by pointing to racial inferiority in others. The bombardment of stereotypes encourages Anglo feelings of superiority over the Mexicans depicted (Aguirre et al., 8-10). An example is the dominant misconception that they are mostly engaged in farm labor; however, 80 percent of Chicanos live in densely populated barrios (7). Other stereotypes offered by many Anglo writers are the portrayal of this minority group as only boxers, school dropouts, gang leaders, revolutionaries and knife-fighters. Unfortunately, many works of the Anglo writers reflect this false process of stereotyping. 


\section{Dr. Ayman Ibrahim Elhalafawy}

In fact, Chicanos are doctors, university teachers, congressmen, lawyers, farm laborers, housewives, and engineers. Unlike the Anglo writers' negative stereotyping, the Chicano writers have pictured the positive stereotypes in their works. Luis Valdez is one of those writers.

Luis Miguel Valdez was born in 1940. He is an American playwright, actor, and film director. Valdez is regarded as the father of Chicano theatre in the United States who is best known for his play Zoot Suit, his movie La Bamba, and his creation of El Teatro Campesino. A pioneer in the Chicano Movement, Valdez broadened the scope of theatre in the Chicano community.

Chicano Theatre is perhaps one of the most important theatres in American literature today and Chicanos everywhere are coming to realize the importance of it for them. Some scholars believe the present Chicano theatre began in 1965 with Luis Valdez and his El Teatro Campesino. Before 1965, Chicano theatre was mostly Christian, reflecting the teachings of the Jesuits. The Church gave the Chicano a tool which it undoubtedly never expected to develop into a socio-political necessity for Chicanos. Not long after El Teatro Campesino began, other teatros appeared, imitating the "Campesino" style.

Nowadays, most theatres are struggling to stay alive presenting "actos," plays, songs and dances based on the Chicano experience. The term "acto" was originally created by Luis Valdez to define the short scenes the Teatro Campesino was performing for the Chicano farmworkers and other audiences. According to Irene Blea (1973), the acto combines characteristics of various dramatic genres: it can be performed most anywhere, props are usually pantomimed, the action can move from one geographic point to another without scene changes, masks are often employed, and it is bilingual. The actos arose out of political expediency. The Teatro Campesino needed material which was relevant to the farmworkers' struggle. Luis guided them through improvisational scenes which resulted in actos. Accordingly, the actos were a very important tool for the farmworkers.

El Teatro Campesino or "The Farmworker's Theatre" is a Chicano theatre company in California. Performing in both English and Spanish, El Teatro Campesino was founded in 1965 as the cultural arm of the United Farm Workers and the Chicano Movement. Valdez brought together farm workers to form El Teatro Campesino, a farm worker's theatre. It was known for touring migrant camps with actos, one-act plays, which were usually around fifteen minutes long. The plays, or actos, were used to educate and inform not only the farm workers, but also the public audience. In this regard, El Teatro's plays were firstly based on the experiences of farm workers. By the time, the play's subject matter 
expanded to other aspects of Chicano culture and succeeded in discussing various Chicano stereotypes.

Most theatres are connected with educational institutions. Some Chicanos join theatre programs in colleges and universities. In 1967, Valdez established a Chicano cultural center in California. Afterwards, in 1969, he moved both theatre and cultural center to Fresno, where he taught at Fresno State College and created TENAZ, the national Chicano theatre organization. The goals of TENAZ are to establish communication between Teatros, provide a means for sharing artistic materials and establish a summer workshop for representatives from different teatros.

Zoot Suit (1979) is a play written by Luis Valdez. It is based on the Sleepy Lagoon murder trial and the Zoot Suit Riots. Zoot Suit was the first Chicano play on Broadway theatre. In 1981, Luis Valdez also directed a filmed version of the play, combining stage and film techniques. Zoot Suit is based on the Sleepy Lagoon Murder of 1942 and the Zoot Suit Riots of 1943 in Los Angeles, California.

Zoot Suit tells the story of Henry Reyna, Mexican-American leader of the 38th Street Gang, and the boys of the 38th Street Gang who were tried for the Sleepy Lagoon murder in Los Angeles, during the Second World War. This gang quarreled with a neighboring gang at the local lovers' lane, Sleepy Lagoon. The 38th Street Gang got into a fight at a party in which a young man was murdered. Discriminated against for their zoot suit wearing Chicano identity, twenty-two members of the 38th Street Gang were placed on trial for the murder. They were found guilty and sentenced to live in San Quentin prison. Meanwhile, in Los Angeles, Henry's brother Rudy was beaten and stripped of his zoot suit during the Zoot Suit Riots.

There were great efforts by George, lawyer of Henry and the 38th Street Gang boys, and other lawyers to free them. In addition, Alice, activist and reporter with whom Henry had a brief romantic encounter, attempted to free the boys by advocating Henry's case. The previously mentioned attempts, finally, helped the boys to win their court appeal and were freed. The play ended with a Reyna family reunion as Henry returned home and his brother, Rudy, was about to leave to join the Marines. The final scene suggests that it is not the happy ending we expect. However, multiple endings of Henry's story are suggested: that he returned to prison and drug abuse, died in the war in Korea and was awarded the Medal of Honor posthumously, or married Della, his girlfriend, and had five Chicano children.

The Chicano nature of the play is clear from the very beginning. El Pachuco, an allegorical character of the Chicano culture of the same 


\section{Dr. Ayman Ibrahim Elhalafawy}

name, introduces the play to the audience drawing a parallel between his own performance as an actor in the play and the pachuco persona as performative. "I speak as an actor on the stage. The Pachuco was existential for he was an actor in the streets, both profane and reverential."'(6). Pachucos wear a specific costume that gives them the confidence to transform into young Chicano men living according to pachuco rules and ethics. This technique allows audiences to judge and make logical decisions about the ethics and Chicano traditions of the play's characters.

The use of Chicanos in the United States' military is a repeated theme in Valdez's play to highlight the discrimination of Chicanos. He criticizes the strategy of the United States government for utilizing Mexican- American soldiers while still treating them as minority or foreigners who cannot receive full civil American rights. For this reason, El Pachuco describes Henry's patriotism as naive. He refers to other countries that are fighting over land, framing the campaign against Mexican Americans in Los Angeles as a colonialist battle.

Muy patriotic, eh?... Off to fight for your country... Because this ain't your country. Look what's happening all around you. The Japs have sewed up the Pacific. Rommel is kicking ass in Egypt but the mayor of L. A. has declared all-out war on Chicanos... Is that what you want to go out and die for? Wise up. These bastard paddy cops have it in for you. You're a marked man. They think you're the enemy. (10)

In the above mentioned quotation, Valdez mirrors the social and racial discrimination of Mexican- Americans in the United States. The American government does not regard Chicanos as American citizens, but as strangers and enemies.

The main conflict that leads to the arrest and unfair trial of the 38th Street Gang is a clash between Mexican-Americans and the dominant Anglo culture. The zoot suitors represented unfamiliar small population of Mexican-Americans. They appeared in duck tailed haircuts and slick suits and promenaded with swaggering coolness, affectations which were seen by some Anglos as an affront to mainstream society.

Valdez seeks to change the negative stereotypes of Chicanos throughout his play. Henry and the boys of the gang are accused of murdering a Mexican-American fellow, Jose Williams. This is not because there was clear evidence of their crime, but because of their ethnic identity and their radical style of dressing and behavior. "That's exactly what the play needs right now. Two more Mexicans killing each other. Watch...everybody's looking at you" (29). According to El 
Pachuco, Mexicans killing each other is what the audience has seen. This implies that the confirmation that Mexican people are violent and the claimed fear of them as a threat is justified. Moreover, the Press describes Mexican Americans as a destructive force that cannot be allowed back into society.

We are dealing with a threat and danger to our children, our families, our home. Set these pachucos free, and you shall unleash the forces of anarchy and destruction in our society. Set these pachucos free and you will turn them into heroes. (47-48)

Valdez's attempts for defending Chicanos and stereotyping them positively are evident in the lawyers' defense for the gang's oppressed members. George Shearer, lawyer for Henry and the 38th Street boys, builds his argument on the fact that Mexican Americans are Americans, not foreigners. When the judge rules that they can't cut their hair or wear clean clothes, George accuses him of forcing them to maintain an appearance that will increase the media bias associated with Mexican Americans that reflects them as dangerous outsiders who are trying to invade an American way of life:

Your Honor, I can only infer that the Prosecution...is trying to make these boys look disreputable, like mobsters... You are trying to exploit the fact that these boys look foreign in appearance! Yet clothes like these are being worn by kids all over America. (Act I, 37-38)

George, like Valdez, attempts to advocate and re-humanize this group of Mexican- American people that has been misrepresented in the American press. He indicates that their trail is based on racial bias rather than clear evidence.

The prosecution has tried to lead you to believe that they are all some kind of inhuman gangsters. Yet they are Americans. Find them guilty of anything more serious than a juvenile bout of fisticuffs, and you will condemn all American youth. Find them guilty of murder, and you will murder the spirit of racial justice in America. (Act I, 48)

Thus, Valdez highlights racism and discrimination once more in his play. Henry's feeling of despair and helplessness is associated with being discriminated and underprivileged in the American society. As a young man growing up in the barrio, his chances for advancement in society have been limited due to prejudice and racism. He is so desperate to move forward in his life that he decides to put his life on the line in the Navy. 


\section{Dr. Ayman Ibrahim Elhalafawy}

As foreigners in their own country, Chicanos suffer from the arrogance and rejection of the Anglo society which forces them to accept a way of life that they do not really understand. "Maybe wanting too much out of life, see? Ever since I was a kid, I've had this feeling like there's a big party going on someplace and I'm invited but I don't know how to get there. And I want to get there so bad; I'll even risk my life to make it. Sounds crazy, huh?" (41).

When Henry returns to the barrio, El Pachuco is waiting for him. El Pachuco represents Henry's old self. Seeing him again, offers hope that Henry can find himself as he was before the trauma of the imprisonment, and trial "It's good to see you again. I thought I'd lost you" (75). Henry Reyna married Della in 1948 and they have five kids "three of them now going to the university,... calling themselves Chicanos. " (83). In this final option for Henry's life, Henry has the potential to leave five different powerful legacies. Two of his children might remain in the barrio to improve the lives of Chicanos who live there. Three of his children attend college and maintain their Chicano pride. In the first choice, he fulfills the prophecy set forth by the media that a pachuco is a criminal with no hope. The second choice brings the glory he seeks but he isn't alive to enjoy it. This third choice allows him to watch his children succeed, and to live in the hope that society can change.

To put it in a nutshell, Valdez's Zoot Suit is a significant Chicano play that successfully dramatizes social injustice and discrimination of Chicanos in America. Valdez seeks to combat the racial prejudice of the Chicano minority. In the play, he dramatizes injustice in order to educate and awaken the American public opinion towards the rights of Chicanos. Thus Valdez's drama aims at correcting the Anglo writers' misrepresentations and stereotypes of Chicanos based on their ignorance about this minority's culture. In addition, it contributes to reduce Anglo's racial superiority by stressing Chicano's positive influence on Anglo society. Concluding his defense for Chicanos, Valdez uses the terms "racial intolerance" and "totalitarian injustice" to summarize their dilemma of discrimination and oppression in America calling for treating them as American citizens:

I have tried my best to defend what is most precious in our American society-a society now at war against the forces of racial intolerance and totalitarian injustice. (Act I, 48)

Thus, ethnic theatres contribute, effectively, in overcoming ethnic boundaries, helping to create a new world voided of discrimination built on social and cultural tolerance. Chicano stages, today, address general American audience, not only a certain ethnic groups. Chicano theatres insist on the ethnic uniqueness of every cultural community in the 
Stereotyping Chicanos in Ethnic Theatre: A Study of Luis Valdez's Zoot Suit

American society. In this regard, they help to forge links between all those communities and to appreciate diversity as enriching for all people with all kinds of backgrounds. 


\section{Dr. Ayman Ibrahim Elhalafawy}

\section{Works Cited}

Aguirre, Lydia, et al. La Causa Chicana: The Movement for Justice, edited by Margaret M. Mangold, New York, Family Service Association of America, 1972. Print.

Blea, Irene. Chicanas and Latinas within a Global Context: Women of Color at the Fourth World Women's Conference. Westport, CT: Praeger, 1997. Web

---. Concerning Teatro Chicano. University of California, Santa Barbara. LATIN AMERICAN THEATRE REVIEW, 1973. Web.

Estrada, William. "The Life and Times of Pío Pico, Last Governor of Mexican California". KCET. Retrieved 2017-06-06, (2016-10-27). Web.

Galda, L. and Bernice E. Cullinan. Literature and the Child. Toonto, CA: Wasworth Tomson Learning, 2006. Print.

Gonzalez et al. Chicano Voices, edited by Carlota Cârdenas de Duyer, Boston: The new American Mifflin, 1975. Print.

Jenkins, Esther C. and Mary C. Austin. Literature for Children about Asians and Asian Americans: Analysis and Annotated Bibliography, with Additional Reading for Adults. New York: Greenwood Press, 1987. Print.

Krasner, David. A Companion to Twentieth-century American Drama. Blackwell: Blackwell Publishing, 2005. Print.

Nadir, Mosche. "I, the Theatre Goer," by permission of the Big Stick (March 1918, reprinted in Etta Block, ed. One Act Plays from the Yiddish. (New York Block Publishing Company, 1929. Print.

Seller, Maxine Schwartz, ed. Ethnic Theatre in the United States. Westport, CT: Greenwood Press, 1983. Print.

Sheilla, Schwartz. Teaching Adolescent Literature: A Humanistic Approach, New Jersey: Hayden Book, 1979. Print.

Steinbeck, John et al. The Chicano: From Caricature to Self-Portrait, edited by Edward Simmen, New York: The New American Library, (1971). Print.

Valdez, Luis. Zoot Suit .San Juan Bautista: Cucaracha Press, 1979. Print. 